\title{
LONG SHORE SEDIMENT TRANSPORT COMPUTATION FOR HAI HAU BEACH-NAM DINH PROVINCE
}

\author{
NGUYen Manh Hung \\ Institute of Mechanics, NCST of Vietnam
}

\begin{abstract}
Several stretches of shore line in the Red River Delta (RRD) are suffering from severe erosion, especially an area between too large river mouths Balat in the North and Day in the South, known as Hai Hau beach. Several different hypothesis have been put forward to explain this erosion. The cut off of the Ha Lan river mouth (in 1955) which discharged sediment at the upstream end of the beach, possibly affects Hai Hau beach. Also, the construction of Hoa Binh dam in the upstream part of Red river has reduced the sediment supply to the area. In this study, it is shown that the prevailing wave climate in connection with the complex topography of Balat river mouth and Hai Hau beach promotes erosion along the coastal line. A two dimensional random wave transformation model was used with 20-year time series of hindcast waves to compute the long shore sediment transport along the study beach.
\end{abstract}

\section{Introduction}

Hai Hau district consists of about $34 \mathrm{~km}$ of coastline and $48 \mathrm{~km}$ of river embankment. Despite protection measures, intensive long-term erosion occurs there, posing very serious problems in both economy and social development of Nam Dinh province in particular and of provinces belonged to Red River Delta in general. According to different reports the average rate of erosion ranges from $5-10 \mathrm{~m} /$ year to $30 \mathrm{~m} /$ year. Over the last 90 years, about $15-20 \mathrm{~km}$ long and $2.5 \mathrm{~km}$ wide strip of Hai Hau beach was lost to the sea [9].

In spite of the important of the Hai Hau beach and the other coastal areas of RRD relatively few comprehensive studies have been carried out to calculate the sediment transport and shore line erosion of the studied area. The most difficulty in carrying out such studies is the limited of data on hydrodynamics and sediment transport. So, in order to calculate the sedimentation and coastal line evolution of Hai Hau beach numerical models are necessary tools to apply.

The overall aim of the present study is to calculate the sediment transport of Hai Hau beach based on the long term winds data at Bach Long Vi hydrometeorological station which is situated in the deep sea zone of the gulf of Tonking. Numerical models for wave transformation and sediment transport were used. Because of the complex topography of the Hai Hau beach and nearby areas, a newly developed twodimensional random wave model [3] based on the mild-slope equations (MSE) was employed using 20-year time series of hindcast waves in offshore as input. A long 
shore sediment transport method proposed by Larson and Hanson [4] was utilized to determine the sediment transport volumes at Hai Hau beach. The results of present study show the fact that waves generated by the winter NE monsoon in combination with the complex bottom topography are the main reason of the erosion at Hai Hau beach. Interaction between the topography and the waves produces long shore sediment transport gradient that induces erosion at the study area.

\section{Main hydrodynamical and sedimentary regime of the study area}

The coastal line of Hai Hau province runs in the NE-SW direction and is exposed to the tides and waves from the gulf of Tongkin. Due to the openness of the sea and relative long wave duration, the waves regime at Hai Hau beach is rather severe. The maximum wave height changes from $6,0-8,0 \mathrm{~m}$ in offshore area to $3,0-5,0 \mathrm{~m}$ in the near shore zone. The computed annual average wave heights and periods for the depth of $17 \mathrm{~m}$ offshore of Hai Hau beach, based on 20 years of wind data are tabulated in Table 1 [2].

Table 1. Computed annual average significant wave height $(\mathrm{H})$, wave period $(\mathrm{T})$ and number of observations $(\mathrm{N})$ at the depth of $17 \mathrm{~m}$ offshore Hai Hau beach [2]

\begin{tabular}{|c|c|c|c|c|c|c|c|c|c|c|}
\hline & $\mathrm{N}$ & NNE & $\mathrm{NE}$ & ENE & $\mathrm{E}$ & ESE & SE & SSE & $S$ & Calm \\
\hline $\mathrm{H}[\mathrm{m}]$ & 1.22 & 1.60 & 2.05 & 1.47 & 1.35 & 1.15 & 1.54 & 1.99 & 1.73 & \\
\hline $\mathrm{T}[\mathrm{s}]$ & 5.0 & 6.0 & 7.0 & 6.0 & 6.0 & 6.0 & 6.0 & 8.0 & 7.0 & \\
\hline $\mathrm{N}$ & 1604 & 3211 & 7962 & 1466 & 3024 & 972 & 1850 & 1415 & 4922 & 2028 \\
\hline
\end{tabular}

Wave transformation in the near shore zone in one hand dynamically acts on the bottom and shore line, in the other hand causes the wave induced current, which carries the sediment out along the shore line. The wave induced current in the surf zone of Hai Hau beach may get to the maximum values of $80-100 \mathrm{~cm} / \mathrm{s}$ [2].

Field observations show that tides are regular diurnal with the height of 2,0 2.5 meters. The predominant tidal flow has the velocity of $25-40 \mathrm{~cm} / \mathrm{s}$ with the directions paralleled to the shoreline, NE during flood tide and SW during ebb tide [7].

Typhoons are often accompanied by storm surge. About $29 \%$ of the recorded typhoons caused storm surges over $1.0 \mathrm{~m}$ and $4 \%$ of them caused storm surges over $2.0 \mathrm{~m}$ [7]. From the statistics it is clear that damages of Hai Hau dyke system often occur during severe NE monsoon coincided with high tide level.

The net annual littoral current is directed southward due to the prevailing influence of NE monsoon in winter. Wind driven currents occur in open sea of Hai Hau beach with the velocities in the range of $15-25 \mathrm{~cm} / \mathrm{s}$. Table 2 shows the calculated monthly wind driven current offshore of Hai Hau beach. 
Table 2. The calculated wind driven current off shore of Hai Hau beach [6]

\begin{tabular}{lcccccccccccc}
\hline Months & 1 & 2 & 3 & 4 & 5 & 6 & 7 & 8 & 9 & 10 & 11 & 12 \\
\hline $\mathrm{V}[\mathrm{cm} / \mathrm{s}]$ & 21 & 21 & $\frac{13}{11}$ & $\frac{12}{13}$ & $\frac{1}{13}$ & $\frac{11}{12}$ & $\frac{1}{16}$ & $\frac{22}{22}$ & $\frac{2}{22}$ \\
$\alpha[\mathrm{deg}]$. & 246 & 246 & 245 & 181 & 170 & 169 & 170 & 170 & 245 & 245 & 246 & 246 \\
\hline
\end{tabular}

The sediment which is typically found at the Hai Hau beach consists of fine sand with the mean grain size about $0.10 \mathrm{~mm}$. The bottom slope is rather gentle (0.006-0.008) which creates a wide zone for wave energy dissipation.

3. Wave transformation and sediment transport calculation

\subsection{Offshore waves}

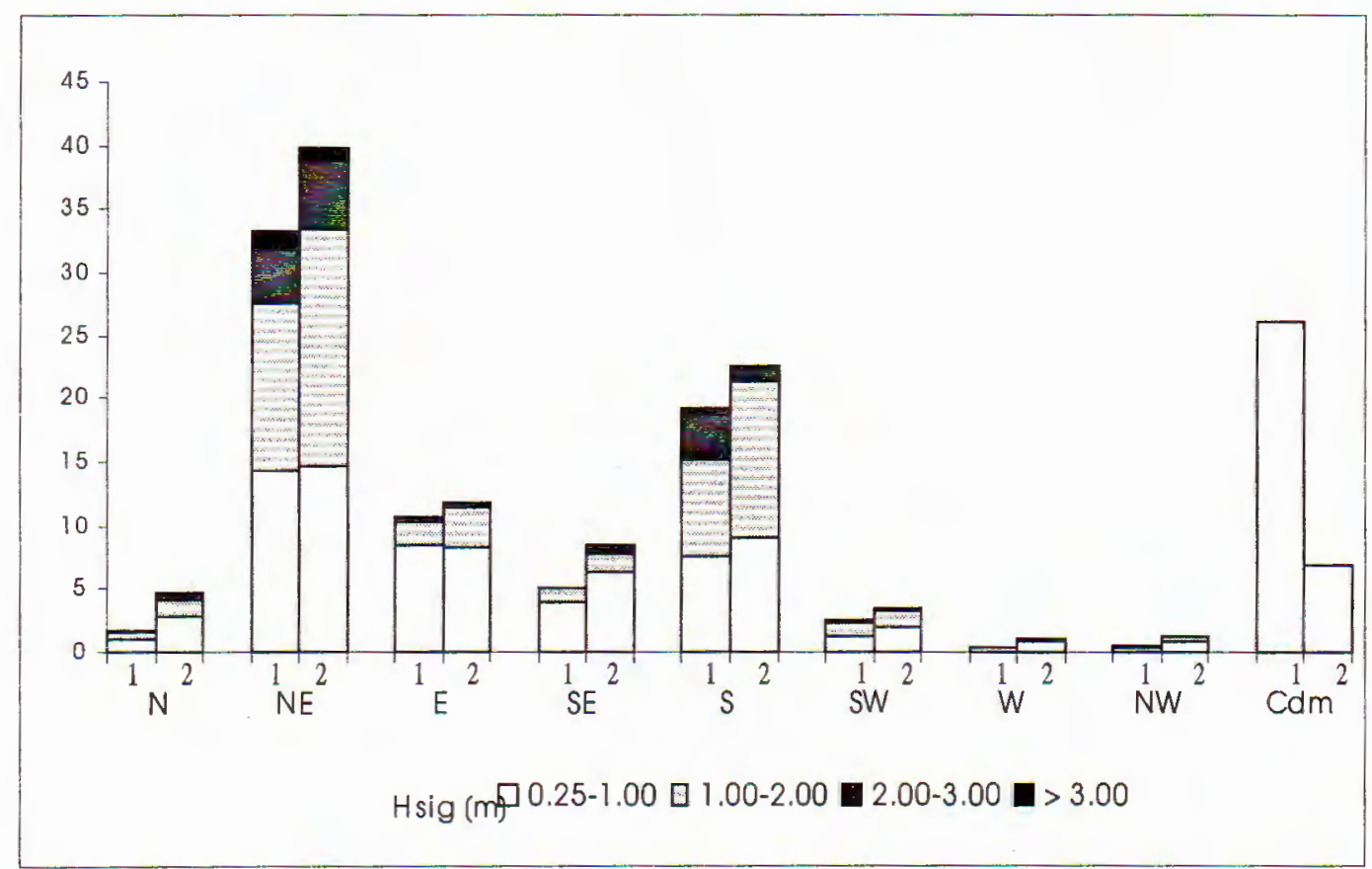

Fig. 1. Measured (2) and calculated (1)

frequency of significant wave heights in the deep sea zone of Hai Hau beach [5]

The data set encompassing 20 years of measured wind speed and direction at Bach Long Vi station (6-hour interval) was employed to calculate offshore wave parameters by using the wave forecasting method of Sverdrup, Munk and Bretschneider (SMB) recommended in SPM 1984 [8]. The wave prediction method SMB were first 
validated through comparison with 20 years of observed wave heights and periods carried also at Bach Long Vi station. Figures 1 and 2 show the measured and calculated frequency of occurrence for wave heights and periods with respect to directions. Overall, the computed wave heights, periods and directions agree well with the observations. According to the results in the Figs. 1 and 2, the wave regime in the gulf of Tonking is primarily defined by the monsoon wind climate. There are two predominant wave directions NE and S associated with the winter NE and summer SW monsoon respectively.

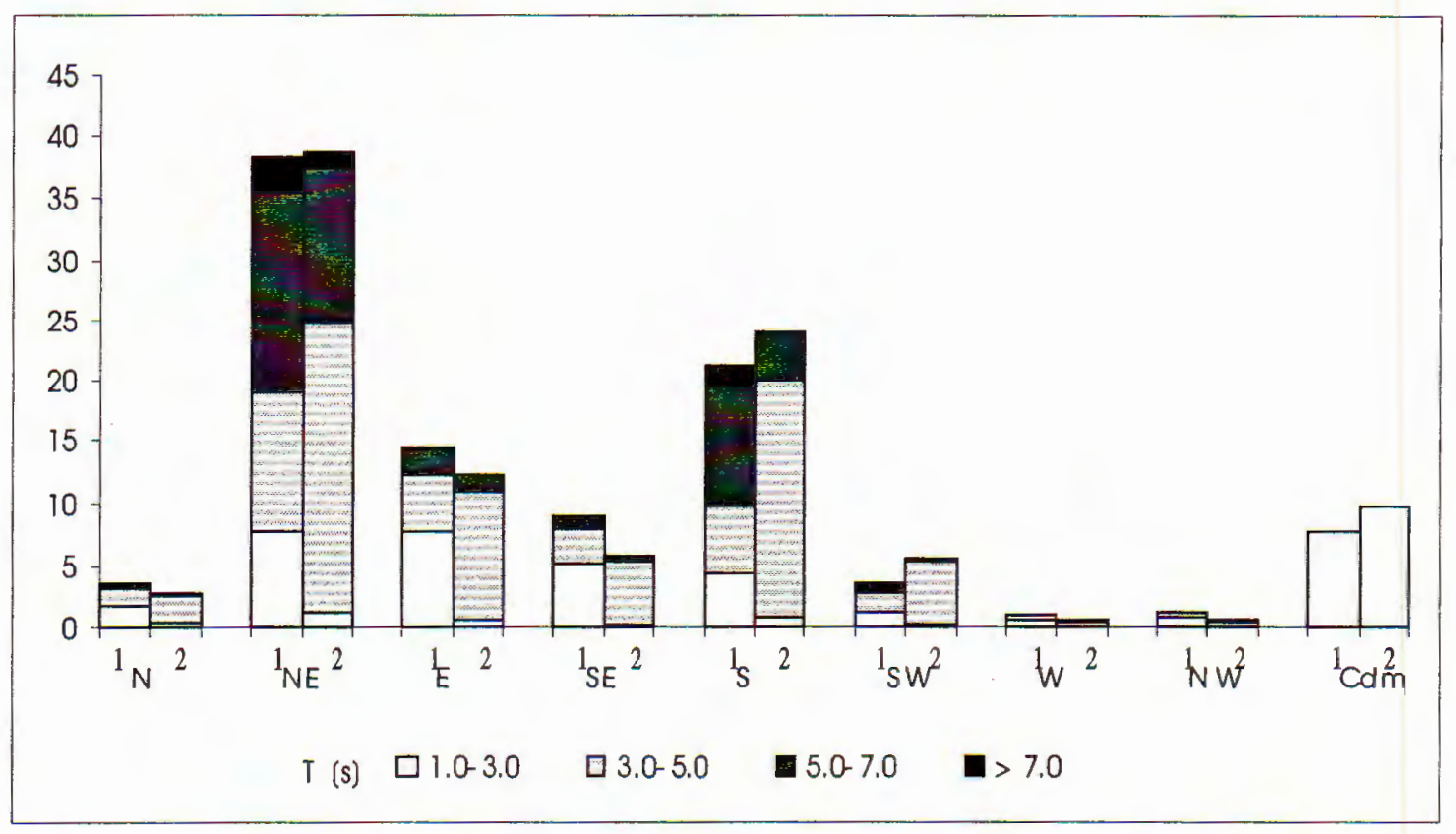

Fig. 2. Measured (2) and calculated (1) frequency of wave periods in the deep sea zone of Hai Hau beach [5]

\subsection{Near shore waves}

The near shore waves were obtained by different methods as:

+ The refraction pattern of the studied area was available by solutions of the wave rays differential equations [2]. Figure 3 shows the wave refraction for the NE wave in the deep zone with the period of $9 \mathrm{~s}$. It is clear that the complex bottom topography makes the wave rays refracted very strongly from Ba Lat river mouth to Hai Hau beach when the waves come to the near shore zone. The wave height at $\mathrm{Ba}$ Lat is higher than at Hai Hau beach because of the convergence effect. This difference results to the increasing of NE-SW net long shore sediment transport along the beach. 


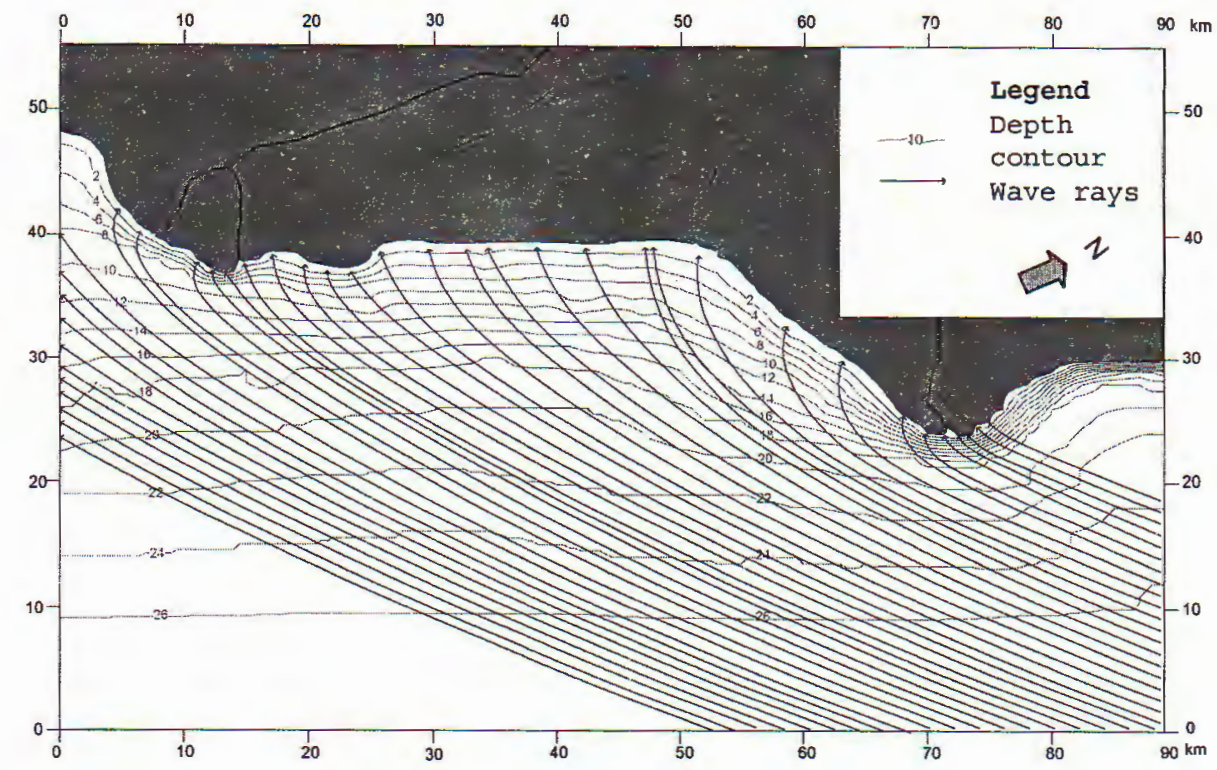

Fig. 3. A wave refraction pattern at Hai Hau coastal zone $(\mathrm{T}=9 \mathrm{~s}-\mathrm{NE})$

+ A numerical two-dimensional random wave transformation model based on the mild-slope equation was employed in the present study to determine the near shore wave condition. Employing the real part of the mild-slope equation with a sink term for depth-limited wave breaking in accordance with Dally, and utilizing a wave-by-wave approach as described by Larson [3] to simulate the randomness in wave height, the following wave energy conservation equation is obtained:

$$
\frac{\partial}{\partial x}\left(F_{r m s} \frac{1}{k} \frac{\partial S}{\partial x}\right)+\frac{\partial}{\partial y}\left(F_{r m s} \frac{1}{k} \frac{\partial S}{\partial y}\right)=\frac{\kappa}{d}\left(F_{r m s}-F_{s t a b}\right),
$$

where $F_{r m s}$ is the wave energy flux based on the root-mean-square (RMS) wave height $\left(H_{r m s}\right), k$-the wave number, $S$-a phase function, $x$ and $y$-coordinates in a rectilinear system (cross-shore and long-shore directions respectively), $(\kappa$-an empirical dissipation coefficient (about 0,15 ), and the equivalent stable wave energy flux for random waves is defined as:

$$
F_{s t a b l}=\beta F_{m}+\mu F_{r}+\alpha(\Gamma / \gamma)^{2} F_{b},
$$

where $\alpha, \beta$ and $\mu$ are the ratio of breaking, unbroken, and reformed wavesrespectively, $F_{m}$ and $F_{r}$ are the wave energy fluxes based on the RMS wave height for the unbroken and reformed waves respectively. The energy flux $F_{b}$ is based on the wave height corresponding to incipient breaking at the specific depth $H_{b}=\gamma_{b} d$, where 
$\gamma_{b}$ is the breaker index. The phase function $S$ is determined by solving the MSE, neglecting diffraction, thus:

$$
\frac{\partial}{\partial x}(|\nabla S| \sin \theta)-\frac{\partial}{\partial y}(|\nabla S| \cos \theta)=0,
$$

where $\nabla$ denotes the horizontal gradient operation, $\theta$ is the local wave direction.

In equation (3.1) $F_{r m s}$ is the primary unknown that should be solved for, implying that $\alpha, \beta, \mu, F_{m}, F_{r}$ and $F_{b}$ must be supplied before the calculation. Once $F_{r m s}$ has been determined everywhere, other wave quantities can be derived, for example, the average energy dissipation $P=\kappa / d\left(F_{r m s}-F_{s t a b}\right)$.

For a beach where the depth is decreasing monotonically in the direction of the approaching waves, $\alpha$ is determined directly from the truncated Rayleigh distribution of wave height through:

$$
\alpha=e^{-F_{b} / F_{x}}
$$

where $F_{x}$ is the local RMS wave height neglecting wave breaking. In order to calculate $\alpha, F_{x}$ has to be obtained everywhere, which is done by solving the wave energy flux equation (3.1) without including energy dissipation due to breaking. The ratio of unbroken waves is given by:

$$
\beta=1-\alpha
$$

The energy flux based on the RMS height of the unbroken waves may be calculated from the truncated local Rayleigh distribution of wave height yielding:

$$
F_{m}=\frac{1}{\beta}\left[F_{x}-(1-\beta)\left(F_{x}+F_{b}\right)\right] .
$$

From the Snell law:

$$
\frac{\sin \theta}{C}=\frac{\sin \theta_{0}}{C_{0}}
$$

where $C_{0}$ is the deep-water wave celerity (defined to be $g T / 2 \pi$ ), an estimate of the local wave direction $\left(\theta_{0}\right)$ is calculated everywhere assuming that the bottom contours are parallel with the $y$-axis.

Wave heights at each grid are estimated as:

$$
H=H_{0}\left(\frac{\cos \theta_{0}}{\cos \theta}\right)^{0.5}\left[\frac{1}{\left(1+\frac{2 k d}{\sinh (2 k d)}\right) \tanh (k d)}\right] .
$$

More detail about the numerical two-dimensional random wave transformation model for the near shore waves transformation can be seen from the reference [ 6 ]. 
Model input includes values of the deep-water wave height $H_{0}$, wave direction $\theta_{0}$ and wave period $T$.

The initial condition of wave directions $\theta$ and wave heights $H$ at each computation grid are obtained by (3.7) and (3.8) (wave period remain unchangeable from deep- sea to near shore water).

At the solid boundary (coastal line) the boundary condition for wave parameters is "no waves", i.e., all wave energy is dissipated by the bottom.

At the lateral boundaries the wave energy remain constant, i.e., no exchange wave energy across lateral boundaries.

Calculations were performed with the $2 \mathrm{D}$ model for every wave event in 20-year time series and average wave properties were computed at each grid point. The coordinate system was oriented along the shore line of Van Ly - Hai Hau province and grid cells with $\Delta x=50 \mathrm{~m}, \Delta y=600 \mathrm{~m}$. Figure 4 depicts the wave height distribution in the near shore zone of Hai Hau beach with the deep sea wave height $H_{s i g}=2.5 \mathrm{~m}$, wave period $T=9 \mathrm{~s}$ and deep sea wave direction $\mathrm{NE}$.

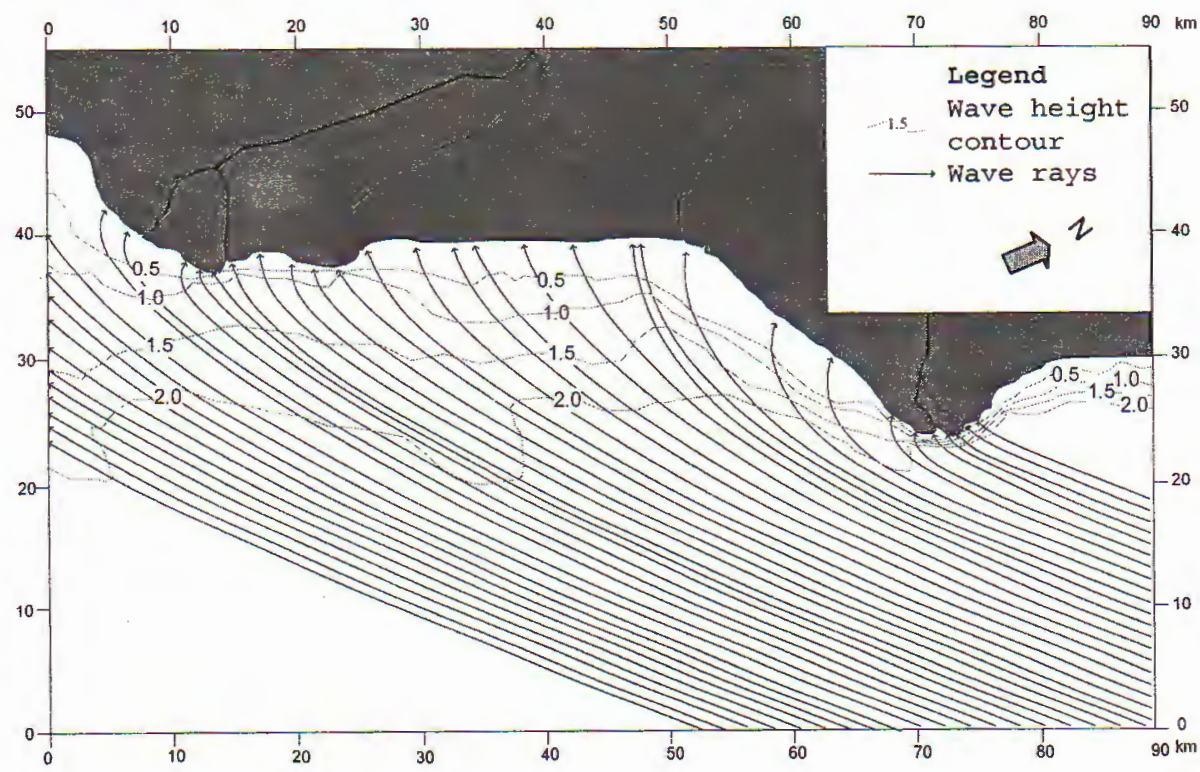

Fig. 4. A distribution of wave height at Hai Hau coastal zone

$(\mathrm{H}$ deep $=2.5 \mathrm{~m}-\mathrm{T}=9.0 \mathrm{~s}-\mathrm{NE})$

\subsection{Sediment transport}

The time series of near shore wave parameters obtained from the $2 \mathrm{D}$ wave transformation calculations were used to compute local long shore sediment transport values. The following formula proposed by Larson and Hanson [4] were used: 


$$
Q_{\ell}=\frac{\varepsilon_{c}}{1-a} \frac{1}{\rho_{s}-\rho} \frac{1}{g w} V P,
$$

where $\varepsilon_{c}$ is a coefficient-transport efficiency factor, $a$-the porosity, $\rho_{s}$ and $\rho$-the density of sediment and water, respectively, $w$-the sediment fall velocity, $V$-the long shore current velocity and $P$-the energy dissipation. The local current velocity was estimated from the balance between the radiation stress gradient and bottom friction. $\varepsilon_{c}$ was determined through comparison with the formula of the Coastal Engineering Research Center (CERC) [8]. By the comparison the following formula was used $\varepsilon_{c}=0.77 C_{f} K$, where $C_{f}$ is the bottom friction and $K$-the transport coefficient in the CERC formula. Because $C_{f}$ appears both in $\varepsilon_{c}$ and $V$, it will cancel out from the calculation. The coefficient $K$ was assigned by the standard value in accordance with SPM 84 [8].

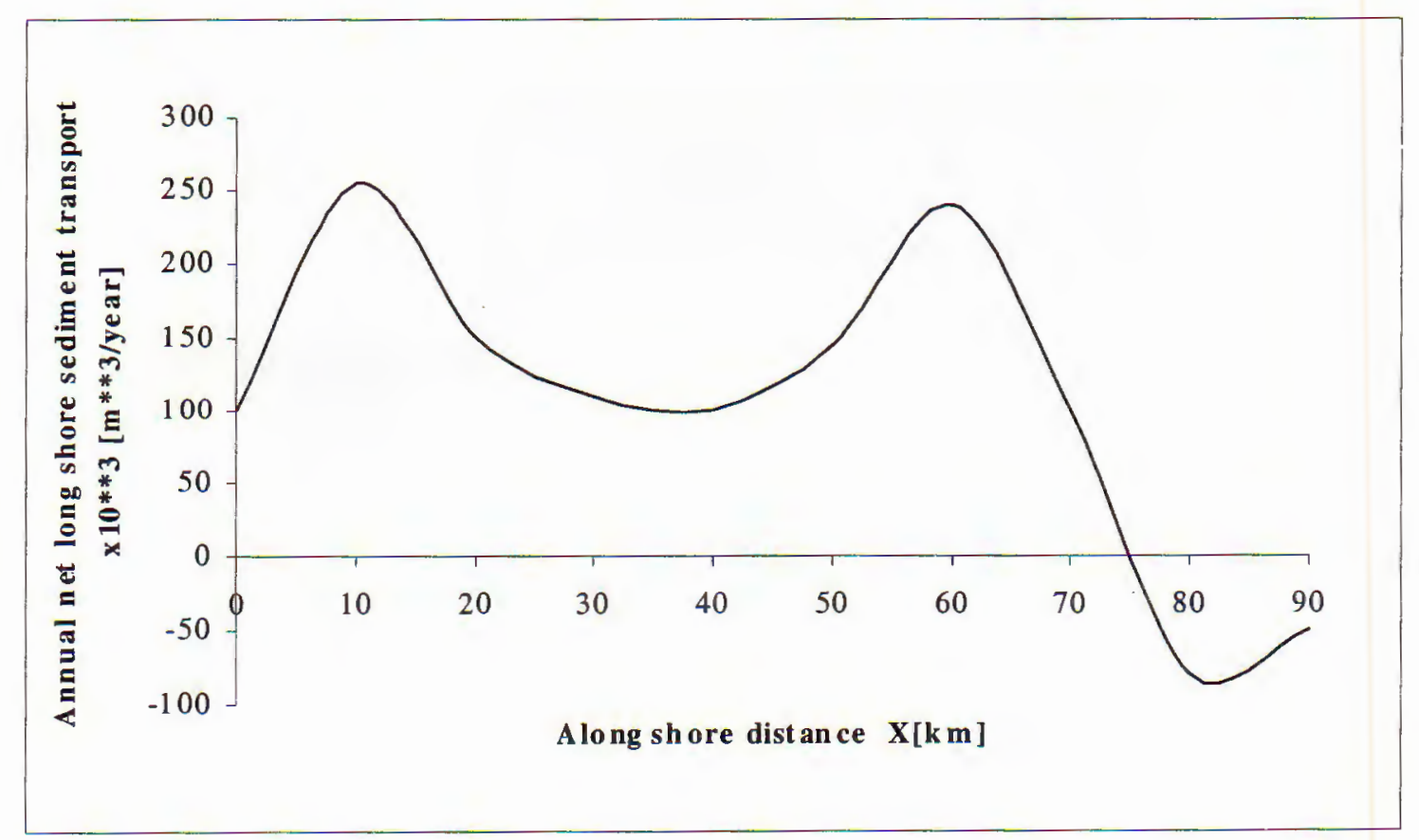

Fig. 5. Mean annual net long shore sediment transport along Hai Hau beach based on wave parameters from 2D wave transformation model.

( + to the South ; - to the North)

Figure 5 shows the mean annual net long shore sediment transport rate along the coastal line of Hai Hau beach obtained by integration in the cross-shore direction. The computation is based on the yearly wave parameters computed with $2 \mathrm{D}$ wave transformation model employed for 20-year time series of offshore wave. In general, 
the obtained results are in good agreement with the hypothesis that the wave climate in combination with the bottom topography is the cause of erosion at Hai Hau beach. The net sediment transport along Hai Hau beach increases at a low rate from the northern end, but toward the southern end it increases quite seriously.

\section{Conclusion}

Hai Hau beach has been eroding for a long time from the beginning of the 20th century. Some hypotheses have been put forward to explain the phenomenon, including the construction of Hoa Binh dam in the upstream part of the Red river (the trapping of sediment leads in to reducing sediment supply to the beach), the cutting of Ha Lan river (which formerly supplied sediment to Hai Hau beach) and interaction between wave climate with bottom topography (which makes the imbalance between waves regime and shore line orientation). Our computation results support the last hypothese. Wave transformation calculations, taking into account the complex topography of Hai Hau beach and together with computed local net sediment transport rate produce rather big long shore gradient of sediment transport rate and this gradient causes the erosion of Hai Hau beach. Hai Hau beach is located downdrift an area of marked accumulation (Ba Lat river mouth) which occurring especially during the summer season (rainy season). This accumulation creates conditions similar to a barrier for long shore sediment transport during winter season - NE monsoon (i.e., a "natural groin") resulting in the erosion in the beach (as second working principle of a groin - SPM 1984 [8]). In order for the erosion to be ceased, a shoreline shape must evolve that is in equilibrium with the wave climate, which in turn is a function of the complex bottom topography. Some approximate estimates of the equilibrium shoreline shape could be made based on the work of Hsu et al. [1].

The results presented in the paper were partly supported by the fundamental research project "Marine Hydrodynamics and Environment, No 32"

\section{REFERENCES}

1. Hsu J., Silvester R. and Xia Y. M. Generalization on static equilibrium bays. Coastal Engineering Vol. 12, 1989.

2. Hung N. M. Wave and sediment transport computation. Final report, National Marine Project KHCN-06.10, Institute of Mechanics, Hanoi, Vietnam 2001 (in Vietnamese).

3. Larson M. Model for decay of random waves in the surf zone. Journal of Waterway, Port, Coastal and Ocean Engineering. Vol. 121, 1995.

4. Larson M. and Hanson H. Schematized numerical model of three-dimensional beach change. 10th Congress of the IAHR Asia and Pacific Division, Langkawi island, Malaixia, Vol. 2, 1996. 
5. Nguyen Manh Hung, M. Larson, Pham Van Ninh, H. Hanson. 2001. Regional wave transformation and associated shoreline evolution in the Red river delta. Ocean wave measurement and analysis. Proceeding of the Fourth Internationnal Symposium Waves 2001. San Francisco, California, 2001.

6. Nguyen Manh Hung, Le Xuan Hoan, Nguyen Thanh Co and Hoang Huu Hung. Modeling of wind driven currents, wave induced current and current related to river discharges in coastal zones and estuaries. Institute of Mechanics, Hanoi, Vietnam 2001 (in Vietnamese).

7. Ninh P. V., Quynh D. N., Lien N. V. Tide, storm surge and near shore circulation computation. Final report, National Marine Project KHCN-06.10, Institute of Mechanics, Hanoi, Vietnam 2001 (in Vietnamese).

8. SPM 1984. Shore protection manual. 4th ed. Vol. 1 US Army Engineer Waterways Experiment Station. Coastal Engineering Research Center. US Government Printing Office, Washington, DC.

9. Zbigniew Pruszak, Marek Szmytkiewicz, Nguyen Manh Hung and Pham Van Ninh. Coastal processes in the Red river delta, Vietnam. Coastal Engineering Journal, Vol. 44. 2002. No.2.

Received September 20, 2002

\section{TÍNH TOÁN VẬN CHUYỂN BÙN CÁT CHO KHU VỰC VEN BỜ BIỂN HẢI HẬU - NAM ĐỊNH}

Khu vực ven bờ biển Hải Hậu tỉnh Nam Định là một vùng bờ biển bị xói lở mạnh trong nhiều năm qua. Đã có một số các giả thiết về nguyên nhân xói lở bờ biển khu vực này trong đó có đề cập đển việc cứa Hà Lạn, là một cửa sông nhỏ phía bắc, bị lấp vào năm 1955 và già thiết về ảnh hương của việc xây đập Hòa Bình ở vùng thượng lưu sông Hồng cũng gây ảnh hưởng đến xói lở khu vực bờ biển Hải Hậu. Tác giả đã tập trung vào giả thiết về nguyên nhân xói lở khu vưc ven bờ biển Hải Hậu là do ảnh hường của gradient trường sóng (chủ yếu trong gió mùa đông bắc) gây ra khi sóng truyền vào vùng ven bờ biển với địa hình đáy phức tạp, do ảnh hưởng của vùng bồi phía ngoài khơi của $\mathrm{Ba}$ Lạt.

Đã sử dụng mô hình tính sóng hai chiều và phương pháp tính toán dòng vận chuyển bùn cát $(\mathrm{VCBC})$ dọc bờ của Hanson $\mathrm{H}$. và $\mathrm{M}$. Larson để tính sóng và VCBC với chuỗi số liệu sóng vùng khơi 20 năm (1 ngày 4 số liệu) tính từ trường gió quan trắc tại trạm Bạch Long Vĩ. Các kết quả tính toán dòng VCBC cho thấy tại khu vực ven bờ biển Hải Hậu tồn tại gradient dương của dòng VCBC xuống phía nam, gây ra xói lở bờ biển. Ảnh hường của địa hình đáy biển phía ngoài khơi của $\mathrm{Ba}$ Lạt đóng vai trò như là một mó hàn tự nhiên trong mùa gió đông bắc và dẫn đến sự tồn tại gradient dòng VCBC và hiện tượng xói lở khu vực ven bờ biển Hải Hậu. 